\title{
Kepemilikan Institusional sebagai Pemoderasi Pengaruh Perencanaan Pajak dan Profitabilitas pada Manajemen Laba
}

\author{
I Made Dwi Sumba Wirawan ${ }^{1}$ \\ Sekolah Vokasi D4 Akuntansi Perpajakan \\ Universitas Warmadewa, Indonesia
}

\begin{abstract}
Surel :dwiisumba@gmail.com
ABSTRAK

Penelitian ini menguji pengaruh perencanaan pajak dan profitabilitas pada manajemen laba. Selain itu, penelitian ini juga menguji kemampuan kepemilikan institusional sebagai variabel pemoderasi. Jumlah sampel yang dianalisis sebanyak 75 sampel perusahaan manufaktur sektor barang konsumsi yang terdaftar di Bursa Efek Indonesia (BEI) selama lima tahun. Metode penentuan sampel adalah nonprobability dengan teknik purposive sampling. Teknik analisis yang digunakan adalah regresi linear berganda dan Moderated Regression Analysis (MRA). Hasil analisis menunjukkan bahwa perencaaan pajak berpengaruh positif pada manajemen laba. Namun profitabilitas tidak berpengaruh pada manajemen laba. Kepemilikan institusional memperlemah perencanaan pajak pada manajemen laba. Namun, kepemilikan institusional tidak memoderasi pengaruh profitabilitas pada manajemen laba.
\end{abstract}

Kata Kunci: Perencanaan Pajak; Profitabilitas; Manajemen Laba; Kepemilikan Institusional.

\section{Institutional Ownership Moderates The Effect of Tax Planning And Profitability on Earnings Management}

\begin{abstract}
This study examines the effect of tax planning and profitability on earnings management. In addition, this study also examines the ability of institutional ownership as a moderating variable. The number of samples analyzed was 75 samples of manufacturing companies in the consumer goods sector listed on the Indonesia Stock Exchange (BEI) for five years. The sampling method was nonprobability with a purposive sampling technique. The analysis technique used is multiple linear regression and Moderated Regression Analysis (MRA). The results of the analysis show that tax planning has a positive effect on earnings management. However, profitability has no effect on earnings management. Institutional ownership weakens tax planning in earnings management. However, institutional ownership does not moderate the effect of profitability on earnings management.
\end{abstract}

Keywords: Tax Planing; Profitability; Earning Management; Institusional Ownership.

Artikel dapat diakses : https://ojs.unud.ac.id/index.php/Akuntansi/index

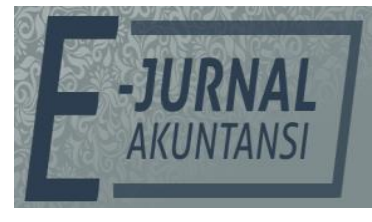

e-ISSN 2302-8556

Vol. 30 No. 9

Denpasar, September 2020

Hal. 2200-2215

DOI:

10.24843/EJA.2020.v30.i09.p03

PENGUTIPAN:

Wirawan, I M. D. S. (2020).

Kepemilikan Institusional sebagai Pemoderasi

Pengaruh Perencanaan Pajak dan Profitabilitas pada

Manajemen Laba. E-Jurnal

Akuntansi, 30(9), 2200-2215

RIWAYAT ARTIKEL:

Artikel Masuk:

25 Juni 2020

Artikel Diterima:

26 Agustus 2020 


\section{PENDAHULUAN}

Laporan keuangan berfungsi sebagai alat untuk mengkomunikasikan data keuangan serta aktivitas perusahaan kepada pihak-pihak yang berkepentingan (Yahya \& Wahyuningsih, 2019). Tujuan laporan keuangan adalah untuk memberikan informasi mengenai posisi keuangan, kinerja keuangan, dan arus kas entitas yang bermanfaat bagi sebagian besar pengguna laporan keuangan dalam pembuatan keputusan ekonomi (PSAK,2017:1). Dalam menyajikan informasi pada laporan keuangan sebaiknya memberikan suatu gambaran mengenai bagaimana kondisi kinerja suatu perusahaan yang sebenarnya, sehingga informasi tersebut dapat digunakan sebagai acuan untuk mengambil keputusan dalam melakukan kerjasama terhadap pihak lain yang memiliki kepentingan dengan perusahaan (Aminah \& Zulaikha, 2019).

Salah satu ukuran kinerja perusahaan yang sering digunakan sebagai pengambilan keputusan bisnis adalah laba yang dihasilkan perusahaan (Sari et al., 2018). Informasi tentang laba (earnings) mempunyai peran sangat penting bagi pihak yang berkepentingan terhadap suatu perusahaan. Dalam menganalisis laporan keuangan baik pihak internal maupun eksternal, laba sering digunakan sebagai dasar untuk pembuatan keputusan seperti pemberian kompensasi dan pembagian bonus kepada manajer, ukuran prestasi atau kinerja manajemen dan dasar penentuan besarnya pengenaan pajak. Sehingga, informasi laba menjadi pusat perhatian bagi investor, kreditor, pembuat kebijakan akuntansi, dan pemerintah dalam hal ini adalah Direktorat Jendral Pajak (Prasetyo et al., 2019).

Pentingnya informasi laba tersebut merupakan tanggungjawab dari pihak manajemen yang diukur kinerjanya dari pencapaian laba yang diperoleh (Sutrisno et al., 2018). Sehingga manajemen berusaha untuk mencapai target laba agar memperoleh manfaat dari apa yang telah dilakukannya (Achyani \& Lestari, 2019). Dalam memenuhi target laba yang ingin dicapai, manajemen perusahaan melakukan tindakan yang disebut sebagai manajemen laba (Yahya \& Wahyuningsih, 2019). Manajemen laba merupakan upaya yang dilakukan pihak manajemen untuk melakukan intervensi dalam penyusunan laporan keuangan dengan tujuan untuk menguntungkan dirinya sendiri, yaitu pihak perusahaan yang terkait (Aditama \& Purwaningsih, 2014).

Terdapat berbagai kasus tentang manajemen seperti PT. Kimia Farma Tbk. Pada tahun 2002 mengindikasikan adanya praktik manajemen akrual dengan menaikan laba hingga Rp 32,7 milyar, sama dengan PT. Indofarma pada tahun 2004 dengan menaikan laba bersih senilai Rp 28,870 milyar, sebagai dampak dari penilaian persediaan barang dalam proses yang lebih tinggi dari yang seharusnya, sehingga harga pokok penjualan tahun tersebut understated (Khuwailid \& Hidayat, 2017). Selain itu, manajemen laba juga dilakukan oleh PT Inovisi Infracom Tbk ditemukan indikasi salah saji dalam laporan keuangan periode September 2014. Pada periode semester pertama 2014 pembayaran gaji pada karyawan Rp1,9 triliun. Namun, pada kuartal ketiga 2014 angka pembayaran gaji pada karyawan turun menjadi Rp59 miliar (Erawati \& Lestari, 2019).

Konsep mengenai manajemen laba dapat dijelaskan dengan menggunakan pendekatan teori keagenan (agency theory). Teori tersebut menyatakan bahwa 
praktik manajemen laba dipengaruhi oleh konflik kepentingan antara pihak yang berkepentingan (principal) dengan manajemen sebagai pihak yang menjalankan kepentingan (agent). Konflik ini muncul pada saat setiap pihak berusaha untuk mencapai tingkat kemakmuran yang diinginkannya (Negara \& Suputra, 2017). Sebagai agen, manajer secara moral bertanggungjawab untuk mengoptimalkan keuntungan para pemilik (principal) dan sebagai imbalannya akan memperoleh kompensasi sesuai dengan kontrak. Dengan demikian terdapat dua kepentingan yang berbeda didalam perusahaan dimana masing-masing pihak berusaha untuk mencapai atau untuk mempertahankan tingkat kemakmuran yang dikehendaki (Asih, 2014).

Tingkat rendah tingginya terjadinya manipulasi laporan keuangan yang dilakukan oleh manajemen dapat disebabkan oleh beberapa faktor. Faktor yang pertama yang mempengaruhi yaitu perencanaan pajak (Erawati \& Lestari, 2019). Di Indonesia pajak merupakan penerimaan Negara yang terbesar dibandingkan dengan penerimaan Negara yang lainnya, begitu besarnya peranan sektor perpajakan dalam mendukung penerimaan Negara. Kondisi perekonomian saat ini telah menciptakan suatu persaingan yang ketat antar perusahaan. Persaingan ini membuat perusahaan harus mampu mengelola keuangannya dengan baik untuk mendapatkan laba (Dewi \& Noviari, 2017).

Perencanaan pajak (tax planning) merupakan salah satu fungsi dari manajemen pajak yang digunakan untuk mengestimasi jumlah pajak yang akan dibayar dan hal-hal yang dapat dilakukan untuk menghindari pajak. Isu dalam penelitian ini adalah adanya motif perencanaan pajak yang digunakan perusahaan untuk melakukan penghematan pajak yang tidak sesuai dengan peraturan perpajakan. Terungkapnya kasus penggelapan pajak yang dilakukan oleh beberapa perusahaan di Indonesia membuktikan bahwa perusahaan melakukan perencanaan pajak yang agresif dengan cara melakukan pembiayaan fiktif, transaksi ekspor fiktif, dan transfer pricing untuk merekayasa omzet penjualan (Astutik \& Mildawati, 2016). Kasus perpajakan juga terjadi di tahun 2007, dimana PT Kaltim Prima Coal (KPC) melakukan rekayasa penjualan untuk meminimalkan pajaknya. Setelah dilakukan penyelidikan oleh Ditjen Pajak, KPC ditemukan pajak kurang bayar sebesar Rp 1,5 trilyun. Dengan melakukan rekayasa penjualan merupakan salah satu praktik manajemen laba (Setyawan \& Harnovinsah, 2016).

Faktor lainnya yang bisa mempengaruhi manajemen laba adalah profitabilitas. Perusahaan yang memiliki profitabilitas yang tinggi akan menghasilkan laba yang tinggi, sehingga berhubungan dengan jumlah kompensasi atau bonus yang diterima manajemen. Gayatrie (2014) menyatakan bahwa perusahaan dapat menggunakan kebijakan kompensasi dalam bentuk bonus berfungsi untuk menyesuaikan prosedur akuntansi yang terkait dengan laba perusahaan. Jadi perusahaan yang memiliki profitabilitas yang tinggi akan semakin besar kemungkinannya melakukan praktik manajemen laba (Setyawan \& Harnovinsah, 2016).

Adanya kepemilikan oleh institusional akan mendorong peningkatan pengawasan yang lebih optimal (Sumanto et al., 2014). Jika terjadi pengawasan mengenai kinerja perusahaan, maka akan menekan manajer dalam melakukan tindakan manajemen laba dan perusahaan dalam melakukan manajemen laba 
dengan diskresi akrual yang susuai dengan PSAK dan ketentuan perpajakan (Khuwailid \& Hidayat, 2017). Menurut Nurrahman \& Sudarno (2013), tingkat kepemilikan institusional yang tinggi akan menimbulkan usaha pengawasan yang lebih besar dri investor institusional sehingga akan menghalangi perilaku opportunistik manajer. Semakin besar kepemilikan institusional maka semakin efisien pemanfaatan aktiva perusahaan dan diharapkan juga dapat bertindak sebagai pencegahan terhadap pemborosan yang dilakukan oleh manajemen.

Penelitian mengenai pengaruh perencanaan pajak pada manajemen laba sudah banyak diteliti oleh beberapa peneliti terdahulu, beberapa di antaranya adalah Yin \& Cheng (2004) serta Sumomba \& Hutomo (2012) yang membuktikan perencanaan pajak dapat mendeteksi adanya manajemen laba perusahaan. Namun, penelitian Setyawan \& Harnovinsah (2016) menunjukkan hasil penelitian berlawanan yang menyatakan bahwa perencanaan pajak tidak memiliki pengaruh yang signifikan terhadap manajemen laba. Hasil serupa dari penelitian Aditama \& Purwaningsih (2014) yang menyatakan bahwa perencanaan pajak ternyata tidak berpengaruh positif terhadap manajamen laba pada perusahaan nonmanufaktur yang terdaftar di BEI. Penelitian mengenai pengaruh profitabilitas pada manajemen laba juga telah dilakukan oleh Wibisana \& Ratnaningsih (2014) menyatakan bahwa tingkat profitabilitas berpengaruh terhadap tindakan perataan laba yang dilakukan perusahaan, di mana tindakan perataan laba merupakan salah satu metode yang dilakukan perusahaan dalam manajemen laba. Perusahaan yang memperoleh tingkat profitabilitas yang rendah cenderung untuk melakukan income maximization, hal ini disebabkan perusahaan dengan tingkat profitabilitas yang rendah akan memberikan citra kurang baik kepada perusahaan dan akibatnya kinerja dari seorang manajer tampak buruk dimata investor. Manajer cenderung untuk menghindari pelaporan laba yang berfluktuasi agar dapat menggambarkan keadaan perusahaan dalam keadaan kondisi yang sehat (Amanza \& Rahardjo, 2012). Sedangkan penelitian Bestivano (2013) menyatakan bahwa profitabilitas tidak memberikan pengaruh terhadap manajemen laba, karena investor mengabaikan informasi ROA sehingga manajemen mengabaikan profitabilitas.

Hasil penelitian sebelumnya bervariasi, sehingga memberi peluang untuk dilakukan penelitian lanjutan baik yang bersifat pengulangan maupun pengembangan. Perbedaan penelitian ini dari penelitian sebelumnya terletak pada penambahan variabel pemoderasi yaitu kepemilikan institusional dalam kaitan hubungan pengaruh perencanaan pajak dan profitabilitas pada manajemen laba. Adanya kepemilikan institusional akan mampu mengurangi praktik manajemen laba yang dilakukan oleh manajemen yang dimotivasi oleh penghematan pembayaran pajak akibat perencanaan pajak serta kompensasi yang diharapkan dapat diterima dari praktik manajemen terkait dengan profitabilitas.

Berdasarkan latar belakang diatas, adapun rumusan masalah dalam penelitian ini adalah apakah perencanaan pajak dan profitabilitas berpengaruh pada manajemen laba. Apakah kepemilikan institusional mampu memoderasi pengaruh perencanaan pajak dan profitabilitas berpengaruh pada manajemen laba. Penelitian ini dilakukan pada perusahaan sub sektor barang konsumsi yang terdaftar pada Bursa Efek Indonesia (BEI). 
Peran perencanaan pajak dalam praktik manajemen laba secara konseptual dapat dijelaskan dengan teori keagenan dan teori akuntansi positif. Pada teori keagenan, dalam hal ini pemerintah (fiskus) sebagai pihak principal dan manajemen sebagai pihak agent masing-masing memiliki kepentingan yang berbeda dalam hal pembayaran pajak. Manajemen perusahaan berusaha membayar pajak sekecil mungkin karena dengan membayar pajak berarti mengurangi kemampuan ekonomis perusahaan. Di lain pihak, pemerintah (principal) memerlukan dana dari penerimaan pajak untuk membiayai pengeluaran pemerintah. Dengan demikian, terjadi konflik kepentingan antara perusahaan dengan pemerintah, sehingga memotivasi agent meminimalkan beban pajak yang harus dibayar kepada pemerintah (Aditama \& Purwaningsih, 2014). Pemilihan metode untuk meminimalisir beban pajak tersebut merupakan judgement yang di pilih oleh manajemen perusahaan tersebut. Sehingga semakin besar tingkat perencanaan pajak yang dilakukan oleh manajemen maka akan semakin tinggi manajemen laba yang akan terjadi (Yunila \& Aryati, 2018). Penelitian Sutrisno et al. (2018) dan Putra et al. (2018) yang menyatakan bahwa perencanaan pajak secara parsial berpengaruh signifikan terhadap manajemen laba. Berdasarkan landasan teori dan hasil penelitian sebelumnya, penulis merumuskan hipotesis sebagai berikut.

$\mathrm{H}_{1}$ : Perencanaan pajak berpengaruh positif pada manajemen laba.

Profitabilitas adalah tingkat keuntungan bersih yang berhasil diperoleh perusahaan dalam menjalankan operasionalnya. Dalam kaitannya dengan manajemen laba (earning management), profitabilitas dapat mempegaruhi manajer untuk melakukan manajemen laba. Karena jika profitabilitas yang didapat perusahaan rendah, umumnya manajer akan melakukan tindakan manajemen laba untuk menyelamatkan kinerjanya di mata pemilik. Hal ini berkaitan erat dengan usaha manajer untuk menampilkan performa terbaik dari perusahaan yang dipimpinnya (Gunawan et al., 2015). Profitabilitas mendapat perhatian penting, dikarenakan suatu perusahaan dapat berjalan apabila tersebut berada dalam keadaan yang menguntungkan. Modal dari luar akan sulit ditarik oleh perusahaan tanpa adanya keuntungan (Tala \& Karamoy, 2017). Dalam mengukur tingkat profitabilitas dengan perhitungan Return on Assets (ROA), perusahaan yang memiliki profitabilitas tinggi dan berskala besar diharapkan regulator dalam memenuhi kewajiban-kewajiban atas peraturan-peraturan yang berlaku, misalnya kewajiban perpajakan, tanggung jawab sosial, dan lainnya (Setyawan \& Harnovinsah, 2016). Hasil penelitian Prasadhita \& Intani (2017) menyatakan bahwa profitabilitas memiliki pengaruh yang signifikan terhadap manajemen laba. Oleh karena itu, hipotesis kedua ini adalah sebagai berikut.

$\mathrm{H}_{2}$ : Profitabilitas berpengaruh positif pada manajemen laba.

Teori keagenan erupakan teori yang menjelaskan hubungan atau kontrak antara prinsipal (pemilik) dan agen (manajer atau para direktur) (Jensen \& Meckling, 1976). Teori agensi mengasumsikan adanya asimetri informasi, yaitu kondisi di mana agen yang mengelola perusahaan memiliki lebih banyak informasi internal perusahaan daripada prinsipal karena prinsipal tidak mungkin terus-menerus mengamati setiap tindakan yang dilakukan agen (Setyawan \& Harnovinsah, 2016). Kepemilikan institusional dianggap memiliki peran penting dalam melakukan pengawasan terhadap kinerja pihak manajemen 
untuk melakukan tugasnya dengan baik (Lidiawati \& Asyik, 2016). Melalui mekanisme kepemilikan institusional, efektivitas pengelolaan sumber daya perusahaan oleh manajemen dapat diketahui dari informasi yang dihasilkan melalui reaksi pasar atas pengumuman laba (Boediono, 2005). Oleh karena itu kepemilikan institusional dapat menekan kecenderungan manajemen melakukan praktik manajemen laba dan memberikan laporan keuangan yang berkualitas. Manajemen laba (earnings management) dilakukan dengan mempermainkan komponen-komponen akrual dalam laporan keuangan, sebab akrual merupakan komponen yang mudah untuk dipermainkan sesuai dengan keinginan orang yang melakukan pencatatan transaksi dan menyusun laporan keuangan (Sulistyanto, 2008). Manajemen perusahaan berusaha membayar pajak sekecil mungkin karena dengan membayar pajak berarti mengurangi kemampuan ekonomis perusahaan (Aditama \& Purwaningsih, 2014). Adanya kepemilikan institusional dapat memperlemah pengaruh perencanaan pajak terhadap manajemen laba. Oleh karena itu, hipotesis ketiga ini adalah sebagai berikut.

$\mathrm{H}_{3}$ : Kepemilikan institusional memperlemah pengaruh perencanaan pajak pada manajemen laba.

Profitabilitas adalah ukuran mengenai kemampuan perusahaan dalam menghasilkan keuntungan selama periode tertentu. Dalam rasio profitabilitas ini dapat dikatakan sampai sejauh mana keefektifan dari keseluruhan manajemen dalam menciptakan keuntungan bagi perusahaan (Setyawan \& Harnovinsah, 2016). Gayatrie (2014) menyatakan bahwa perusahaan dapat menggunakan kebijakan kompensasi dalam bentuk bonus berfungsi untuk menyesuaikan prosedur akuntansi yang terkait dengan laba perusahaan. Adanya konflik kepentingan dan asimetri informasi itulah yang mendorong manajer (agen) menyajikan informasi yang tidak sebenarnya kepada pemilik (prinsipal). Upaya manajer untuk mengubah, menyembunyikan dan merekayasa angka-angka dalam laporan keuangan dengan mempermainkan metode dan prosedur akuntansi yang digunakan perusahaan sering disebut sebagai manajemen laba. Manajemen laba (earnings management) dilakukan dengan mempermainkan komponen-komponen akrual dalam laporan keuangan, sebab akrual merupakan komponen yang mudah untuk dipermainkan sesuai dengan keinginan orang yang melakukan pencatatan transaksi dan menyusun laporan keuangan (Sulistyanto, 2008).

Kepemilikan institusional memiliki kemampuan untuk mengendalikan pihak manajemen melalui proses monitoring secara efektif sehingga dapat mengurangi tindakan manajemen laba. Hal ini sesuai dengan pendapat Ebtama \& Titik (2013) yang menyatakan bahwa kepemilikan institusional berbanding terbalik dengan manajemen laba dimana jika penambahan persentase saham kepemilikan institusional setiap tahunnya dapat mendorong penurunan praktik manajemen laba. Demikian halnya dengan penelitian yang dilakukan oleh Koh (2003) menemukan bukti bahwa kepemilikan institusional yang tinggi membatasi manajer untuk melakukan pengelolaan laba. Oleh karena itu, hipotesis keempat ini adalah sebagai berikut.

$\mathrm{H}_{4}$ : Kepemilikan institusional memperlemah pengaruh profitabilitas pada manajemen laba. 
Konsep penelitian merupakan hubungan logis dari landasan teori yang telah dijabarkan. Konsep penelitian tersaji pada Gambar 1.

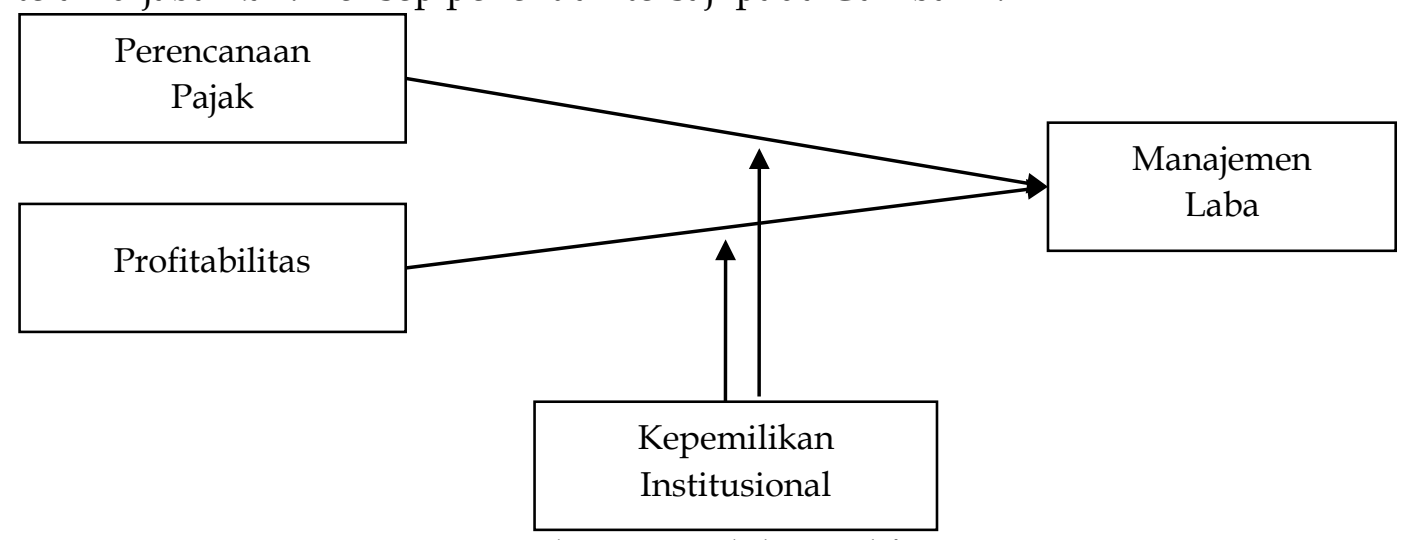

Sumber: Data Penelitian, 2020

\section{METODE PENELITIAN}

Objek Penelitian adalah manajemen laba, populasi sebanyak 38 perusahaan manufaktur sektor industri barang konsumsi yang terdaftar di Bursa Efek Indonesia periode 2014-2018. Metode pengumpulan data yang digunakan adalah dengan metode dokumentasi dimana dalam penelitian ini memperoleh data dari men-download laporan keuangan perusahaan manufaktur sektor industri barang konsumsi yang terdaftar di Bursa Efek Indonesia (BEI) periode 2014-2018 di web resmi Bursa Efek Indonesia (BEI) www.idx.co.id. Teknik pengambilan sampel dilakukan dengan sampling bertujuan (purposive sampling).

Variabel dependen dalam penelitian ini adalah manajemen laba. Manajemen laba ialah sebuah upaya memanipulasi laporan keuangan yang dapat dilakukan pihak internal perusahaan agar mendapat keuntungan pribadi (Aminah \& Zulaikha, 2019). Manajemen laba dalam penelitian ini diproksi menggunakan discretionary accruals, yang dihitung menggunakan Model Jones yang telah dimodifikasi, dengan tahapan awal yaitu menghitung total akrual, sebagai berikut.

$\mathrm{TA}_{\mathrm{cc}}=\mathrm{NI}_{\mathrm{jt}}-\mathrm{CFO}_{\mathrm{jt}}$

Keterangan:

Tacc $=$ total akrual

$\mathrm{NI}_{\text {it }} \quad=$ laba operasi perusahaan i pada tahun $\mathrm{t}$

$\mathrm{CFO}_{\text {it }}=$ arus kas operasional (Cash flow Operating) perusahaan i pada tahun $\mathrm{t}$

Tahap selanjutnya ialah menghitung nilai akrual yang telah diestimasi menggunakan regresi Ordinary Least Square (OLS), sebagai berikut.

$$
T A_{c c i \mathrm{r}} / T A_{\mathrm{it}-1}=\alpha_{1}\left(1 / T A_{\mathrm{it}-1}\right)+\alpha_{2}\left(\frac{\Delta R E V_{\mathrm{it}}-\Delta R E C_{\mathrm{it}}}{T A_{\mathrm{it}-1}}\right)+\alpha_{3}\left(\frac{P P E_{\mathrm{it}}}{T A_{\mathrm{it}-1}}\right)+\varepsilon_{\mathrm{it}}
$$

Keterangan:

$\mathrm{TA}_{\text {ccit }}=$ total akrual perusahaan i pada tahun $\mathrm{t}$

$\mathrm{TA}_{\mathrm{it}-1}=$ total aset perusahaan i pada tahun $\mathrm{t}-1$

$\triangle \mathrm{REV}_{\mathrm{it}}=$ perubahan pendapatan perusahaan i pada tahun $\mathrm{t}$

$\triangle \mathrm{REC}_{\mathrm{it}}=$ perubahan piutang perusahaan $\mathrm{i}$ pada tahun $\mathrm{t}$

$\mathrm{PPE}_{\mathrm{it}}=$ aset tetap (property plant and equipment) perusahaan $\mathrm{i}$ pada tahun $\mathrm{t}$ 
$\begin{aligned} a & =\text { konstanta } \\ \varepsilon & =\text { error }\end{aligned}$

Tahap ketiga adalah mengitung nondiscretionary accruals model (NDA), sebagai berikut.

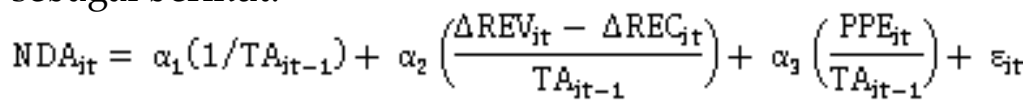

Keterangan:

$\mathrm{NDA}_{i \mathrm{t}}=$ nondiscretionary accruals pada tahun $\mathrm{t}$

$\mathrm{TA}_{\mathrm{it}-1}=$ total aset perusahaan i pada tahun $\mathrm{t}-1$

$\Delta \mathrm{REV}_{\mathrm{it}}=$ perubahan pendapatan perusahaan i pada tahun $\mathrm{t}$

$\triangle \mathrm{REC}_{\mathrm{it}}=$ perubahan piutang perusahaan i pada tahun $\mathrm{t}$

$\mathrm{PPE}_{\mathrm{it}}=$ aset tetap (property plant and equipment) perusahaan $\mathrm{i}$ pada tahun $\mathrm{t}$

$\mathrm{a} \quad=$ konstanta

$\varepsilon \quad=$ error

Tahap terakhir adalah menghitung discretionary accruals dengan cara sebagai berikut.

$\mathrm{DCA}_{\mathrm{ccit}}=\left(\frac{\mathrm{TA}_{\mathrm{crit}}}{\mathrm{TA}_{\mathrm{it}-1}}\right)-\mathrm{NDA}_{\mathrm{jt}}$

Keterangan:

$\mathrm{DCA}_{\text {ccit }}=$ discretionary accruals perusahaan $\mathrm{i}$ pada tahun $\mathrm{t}$

$\mathrm{TA}_{\text {ccit }}=$ total akrual perusahaan i pada tahun $\mathrm{t}$

$\mathrm{TA}_{\mathrm{it}-1}=$ total aset perusahaan i pada tahun $\mathrm{t}-1$

$\mathrm{NDA}_{\mathrm{it}}=$ nondiscretionary accruals pada tahun $\mathrm{t}$

Variabel independen dalam penelitian ini adalah perencanaan pajak dan profitabilitas. Perencanaan pajak adalah langkah yang ditempuh oleh wajib pajak untuk meminimumkan beban pajak tahun berjalan maupun tahun yang akan datang, agar pajak yang dibayar dapat ditekan seefisien mungkin dan dengan berbagai cara yang memenuhi ketentuan perpajakan (Astutik \& Mildawati, 2016). Dalam penelitian ini perencanaan pajak diukur dengan menggunakan rumus tax retention rate (tingkat retensi pajak), yang menganalisis suatu ukuran dari efektivitas manajemen pajak pada laporan keuangan perusahaan tahun berjalan (Wild et al., 2004). Rumus tax retention rate (tingkat retensi pajak) sebagai berikut.

$\mathrm{TRR}_{\mathrm{jt}}=\frac{\mathrm{NI}_{\mathrm{jt}}}{\mathrm{EBIT}_{\mathrm{jt}}}$

Keterangan:

$\mathrm{TRR}_{\mathrm{it}}=$ Tax Retention Rate (tingkat retensi pajak) perusahaan i pada tahun $\mathrm{t}$

$\mathrm{NI}_{\text {it }} \quad=$ Net Income (laba bersih) perusahaan i pada tahun $\mathrm{t}$

$\mathrm{EBIT}_{\mathrm{it}}=$ Pretax Income (laba sebelum pajak) perusahan i tahun $\mathrm{t}$

Rasio profitabilitas menjadi ukuran untuk menunjukkan kemampuan dalam penekanan biaya yang terjadi serta peningkatan penjualan, diukur dengan cara laba bersih dibagi total aset (Rasid, 2018). Profitabilitas diukur dengan rumus sebagai berikut.

Returm on asset $($ ROA $)=\frac{\text { Labo Bersih }}{\text { Total Aset }}$ 
Variabel moderasi dalam penelitian ini adalah kepemilikan institusional. Kepemilikan institusional merupakan saham perusahaan yang dimiliki oleh inst.itusi atau lembaga (perusahaan asuransi, bank, peru.sahaan investasi dan kepemilikan institusi lainnya) (Mahariana \& Ramantha, 2014). Kepemilikan institusional diukur dengan rumus sebagai berikut.

Kepemilikan institusional $=\frac{\text { Jumlah saham yang dimiliki institusi }}{\text { Total saham beredar }} \times 100 \%$

Selain itu, terdapat pula satu variabel kontrol dalam penelitian ini yaitu ukuran perusahaan. Ukuran perusahaan adalah perbandingan antara besar kecilnya suatu perusahaan, sehingga dapat menggambarkan kinerja sebuah perusahaan (Aminah \& Zulaikha, 2019). Ukuran perusahaan dapat diukur dengan menggunakan natural log dari total aset perusahaan pada akhir tahun. Penelitian ini menggunakan metode analisis data Regresi Linier Berganda dan Moderated Regression Analysis (MRA) dengan bantuan aplikasi stastistik SPSS for Windows. Model regresi linear berganda dalam penelitian ini, dinyatakan dengan persamaan sebagai berikut.

$Y=\alpha+\beta_{1} X_{1}+\beta_{2} X_{2}+\varepsilon$

Keterangan:

\begin{tabular}{|c|c|}
\hline$Y$ & = Manajemen Laba \\
\hline$a$ & $=$ Konstanta \\
\hline$X_{1}$ & $=$ Perencanaan Pajak \\
\hline$X_{2}$ & $=$ Profitabilitas \\
\hline$\beta_{1}, \beta_{2}$ & $\begin{array}{l}=\text { Koefisien regresi } \\
=\text { Error }\end{array}$ \\
\hline
\end{tabular}

Model Moderated Regression Analysis (MRA) dalam penelitian ini, dinyatakan dengan persamaan sebagai berikut :

$Y=\alpha+\beta_{1} X_{1}+\beta_{2} X_{2}+\beta_{3} X_{3}+\beta_{4} X_{1} X_{3}+\beta_{5} X_{2} X_{3}+\varepsilon$

Keterangan:

$\begin{array}{ll}Y & =\text { Manajemen Laba } \\ \mathrm{a} & =\text { Konstanta } \\ \mathrm{X}_{1} & =\text { Perencanaan Pajak } \\ \mathrm{X}_{2} & =\text { Profitabilitas } \\ \mathrm{X}_{3} & =\text { Kepemilikan Institusional } \\ \beta_{1, \beta_{2}, \beta_{3}, \beta_{4}, \beta_{5}} & =\text { Koefisien regresi } \\ \varepsilon & =\text { Error }\end{array}$

\section{HASIL DAN PEMBAHASAN}

Berdasarkan data sekunder yang diperoleh dan diseleksi sesuai dengan kriteria yang sudah ditentukan, disajikan pada Tabel 1.

Outlier ialah kasus atau data yang memiliki karakteristik unik dan terlihat sangat berbeda jauh dari observasi-observasi lainnya yang muncul dalam nilai ekstrim (Ghozali, 2012: 41). Salah satu penyebabnya adalah outlier berasal dari populasi yang diambil sebagai sampel, tetapi distribusi dari variabel dalam populasi tersebut memiliki nilai ekstrim, sehingga tidak berdistribusi secara normal. Pada penelitian ini, terdapat data outlier yang dikarenakan oleh proporsi atas kepemilikan institusional. Ada kepemilikan insitusional yang nilainya sangat rendah, karena penelitian dilakukan dalam kurun waktu lima tahun 
sehingga secara total data outlier terlihat banyak. Selain itu, untuk variabel profitabilitas juga terdapat nilai ektrim karena beberapa perusahaan memiliki nilai profitablitas terlalu rendah dan atau bahkan ada yang sangat tinggi.

\section{Tabel 1 . Proses Penentuan Sampel Penelitian}

\begin{tabular}{llc}
\hline No. & \multicolumn{1}{c}{ Kriteria Sampel } & Jumlah \\
\hline 1. & $\begin{array}{l}\text { Perusahaan manufaktur sektor barang konsumsi yang } \\
\text { terdaftar di Bursa Efek Indonesia pada tahun pengamatan }\end{array}$ & 190 \\
& 2014-2018. & \\
2. Perusahaan manufaktur sektor barang konsumsi yang & (29) \\
memeroleh rugi fiskal dan komersial pada tahun pengamatan & \\
2014-2018. & Perusahaan yang tidak memiliki kelengkapan informasi yang \\
dibutuhkan terkait dengan indikator-indikator & $(15)$ \\
$\quad$ Data Oulier & (71) \\
$\quad$ Total sampel penelitian & 75
\end{tabular}

Sumber: Data Penelitian, 2020

Pengujian asumsi klasik meliputi uji normalitas, uji autokorelasi, uji multikolinearitas, dan uji heteroskedastisitas. Pengujian asumsi klasik telah memenuhi uji, sehingga model layak digunakan untuk memprediksi. Tabel 2, menunjukkan hasil pengujian regresi linear berganda dengan signifikansi sebesar 5 persen.

Tabel 2. Hasil Uji Regresi Linier Berganda

\begin{tabular}{lccc}
\hline & Keterangan & Nilai Beta & Signifikansi \\
\hline (Constant) & 0,668 & 0,001 \\
Perencanaan Pajak & 0,610 & 0,002 \\
Profitabilitas & $-0,199$ & 0,163 \\
\hline
\end{tabular}

Sumber: Data Penelitian, 2020

Hipotesis pertama menyatakan bahwa perencanaan pajak berpengaruh positif pada manajemen laba. Tabel 2, menunjukkan bahwa hubungan antara perencanaan pajak pada manajemen laba adalah sebesar 0,610 dengan nilai signifikansi 0,002 lebih kecil dari $\alpha=0,05$ yang berartia bahwa perencanaan pajak berpengaruh positif pada manajemen laba. Berdasarkan hasil penelitian tersebut maka hipotesis pertama diterima.

Peran perencanaan pajak dalam praktik manajemen laba secara konseptual dapat dijelaskan dengan teori keagenan dan teori akuntansi positif. Manajemen perusahaan berusaha membayar pajak sekecil mungkin karena dengan membayar pajak berarti mengurangi kemampuan ekonomis perusahaan (Aditama \& Purwaningsih, 2014). Pemilihan metode untuk meminimalisir beban pajak tersebut merupakan judgement yang di pilih oleh manajemen perusahaan tersebut. Sehingga semakin besar tingkat perencanaan pajak yang dilakukan oleh manajemen maka akan semakin tinggi manajemen laba yang akan terjadi (Yunila \& Aryati, 2018). Hasil penelitian ini mendukung penelitian yang dilakukan oleh Sutrisno et al. (2018) dan Putra et al. (2018) yang menyatakan bahwa perencanaan pajak berpengaruh signifikan terhadap manajemen laba.

Hipotesis kedua menyatakan bahwa profitabilitas berpengaruh positif pada manajemen laba. Tabel 2, menunjukkan bahwa hubungan antara profitabilitas pada manajemen laba adalah negatif sebesar 0,199 dengan nilai signifikansi 0,163 lebih besar dari $a=0,05$ yang berartia bahwa profitabilitas 
Hubungan variabel kepemilikan institusional dengan variabel dependen dapat dilihat dari nilai signifikansi variabel kepemilikan institusional sebesar 0,034 lebih kecil dari $a=0,05$. Sedangkan interaksi variabel kepemilikan institusional dengan variabel independen dapat dilihat dari nilai signifikansi interaksi variabel perencanaan pajak dengan variabel kepemilikan instutional yaitu sebesar 0,044 , lebih kecil dari $a=0,05$. Dengan memperhatikan pengaruh langsung variabel moderasi dengan variabel dependen, dan interaksi antara variabel independen dengan variabel moderasi, maka variabel kepemilikan institusional digolongkan kedalam jenis moderasi semu atau quasi moderator. Quasi moderasi merupakan variabel moderasi yang berhubungan dengan variabel dependen dan atau independen serta berinteraksi dengan variabel independen (Ghozali, 2012:224).

Hasil penelitian ini mendukung teori agensi merupakan teori yang menjelaskan hubungan atau kontrak antara prinsipal (pemilik) dan agen (manajer atau para direktur) (Jensen \& Meckling, 1976). Teori agensi mengasumsikan adanya asimetri informasi, yaitu kondisi di mana agen yang mengelola perusahaan memiliki lebih banyak informasi internal perusahaan daripada prinsipal karena prinsipal tidak mungkin terus-menerus mengamati setiap tindakan yang dilakukan agen (Setyawan \& Harnovinsah, 2016). Kepemilikan institusional dianggap memiliki peran penting dalam melakukan pengawasan terhadap kinerja pihak manajemen untuk melakukan tugasnya dengan baik (Lidiawati \& Asyik, 2016). Melalui mekanisme kepemilikan institusional, efektivitas pengelolaan sumber daya perusahaan oleh manajemen dapat diketahui dari informasi yang dihasilkan melalui reaksi pasar atas pengumuman laba (Boediono, 2005). Oleh karena itu kepemilikan institusional dapat menekan kecenderungan manajemen melakukan praktik manajemen laba dan memberikan laporan keuangan yang berkualitas.

Hipotesis kempat menyatakan bahwa kepemilikan institusional memperlemah pengaruh profitabilitas pada manajemen laba. Dilihat dari nilai signifikansi interaksi profitabilitas dan kepemilikan institusional sebesar 0,067 lebih besar dari $a=0,05$ menunjukkan bahwa kepemilikan institusional tidak mampu memoderasi pengaruh profitabilitas pada manajemen laba. Nilai beta interaksi profitabilitas dan kepemilikan institusional yang bernilai negatif sebesar 1,717 menunjukkan bahwa kepemilikan institusional tidak mampu memoderasi pengaruh profitabilitas pada manajemen laba, maka dari itu hipotesis keempat ditolak.

Dilihat dari pengaruh langsung variabel moderasi, dan interaksi antara variabel independen dengan variabel moderasi, kepemilikan institusional termasuk ke dalam jenis prediktor moderasi. Hal tersebut dilihat dari nilai signifikansi variabel kepemilikan institusional yaitu 0,034 lebih kecil dari $a=$ 0,05 , serta dilihat dari nilai signifikansi interaksi variabel profitabilitas dan kepemilikan institusional yaitu 0,067, lebih besar dari $a=0,05$. Nilai tersebut menunjukkan bahwa variabel kepemilikan institusional bukanlah moderator, melainkan tergolong ke dalam prediktor (independen).

Profitabilitas perusahaan bukan salah satu penyebab manajer melakukan manajemen laba, hal ini dikarenakan profitabilitas perusahaan telah menjadi perhatian utama para pemangku kepentingan sehingga sedikit celah 
bagi manajer untuk dapat melakukan praktik manajemen laba, dengan demikian tinggi atau rendahnya rasio profitabilitas tidak berpengaruh terhadap manajemen laba (Damayanti \& Kawedar, 2018). Adanya kepemilikan institusional tidak mampu memoderasi profitabilitas pada manajemen laba karena walaupun kepemilikan institusional tinggi namun profitabilitas tersebut telah menjadi perhatian utama pemangku kepentingan. Perhatian atas rasio profitabilitas ini walaupun tidak diawasi oleh institusi tertentu tetap saja rasio profitabilitas menjadi perhatian pihak pengguna laporan sehingga adanya kepemilikan institusional tidak tidak mampu memoderasi profitabilitas pada manajemen laba.

\section{SIMPULAN}

Berdasarkan hasil dan pembahasan, maka dapat disimpulkan bahwa perencanaan pajak berpengaruh positif pada manajemen laba. Hal tersebut menunjukkan semakin tinggi perencanaan pajak menyebabkan manajemen laba juga akan semakin tinggi. Profitabilitas tidak berpengaruh pada manajemen laba. Hal tersebut menunjukkan profitabilitas baik tinggi maupun rendah tidak menyebabkan perubahan pada manajemen laba. Kepemilikan institusional memperlemah pengaruh perencanaan pajak pada manajemen laba. Perencanaan pajak yang semakin tinggi menyebabkan manajemen laba juga semakin rendah, adanya kepemilikan institusional akan mengurangi praktik manajemen laba. Kepemilikan institusional tidak memoderasi pengaruh profitabilitas pada manajemen laba. Kepemilikan institusional yang ada di perusahaan tidak mampu memperlemah hubungan profitabilitas sehingga tidak ada perubahan atas praktik manajemen laba.

\section{REFERENSI}

Achyani, F., \& Lestari, S. (2019). Pengaruh Perencanaan Pajak Terhadap Manajemen Laba (Studi Empiris Pada Perusahaan Manufaktur yang Terdaftar di Bursa Efek Indonesia Tahun 2015-2017). Riset Akuntansi Dan Keuangan Indonesia, 4(1), 77-88. https://doi.org/10.23917/ reaksi.v4i1.8063

Aditama, F., \& Purwaningsih, A. (2014). Pengaruh Perencaaan Pajak Terhadap Manajemen Laba Pada Perusahaan Nonmanufaktur Yang Terdaftar di Bursa Efek Indonesia. Modus, 26(1), 33-50. https:/ / doi.org/10.24002/modus.v26i1.576

Amanza, A. H., \& Rahardjo, S. N. (2012). Analisis Faktor-Faktor Yang Mempengaruhi Praktik Perataan Laba ( Income Smoothing ). Diponegoro Journal of Accounting, 1(1), 1-13. http://ejournals1.undip.ac.id/index.php/accounting\%0AANALISIS

Aminah, S., \& Zulaikha. (2019). Pengaruh Aset Pajak Tangguhan, Konsentrasi Kepemilikan, Dan Ukuran Perusahaan Terhadap Manajemen Laba. Diponegoro Journal of Accounting, 8(3), 1-12.

Asih, P. (2014). Fakor- Faktor yang Mempengaruhi Praktik Manajmen Laba (Studi Kasus: Perusahaan Manufaktur yang Terdaftar di BEI. Jurnal TEKUN, $V(02), 191-201$.

Astutik, R. E. P., \& Mildawati, T. (2016). Pengaruh Perencanaan Pajak dan Beban Pajak Tangguhan Terhadap Manajemen Laba. Jurnal Ilmu Dan Riset 
Akuntansi, 5(3), 1-17.

Bestivano, W. (2013). Pengaruh Ukuran Perusahaan, Umur Perusahaan, Profitabilitas, dan Leverage Terhadap Perataan Laba Pada Perusahaan yang Terdaftar di BEI (Studi Empiris pada Perusahaan Perbankan). Jurnal Akuntansi Universitas Negeri Padang, 1(1), 1-28. http://journal.wima.ac.id/index.php/JIMA/article/view/255

Boediono, G. S. (2005). Kualitas Laba: Studi Pengaruh Mekanisme Corporate Governance dan Dampak Manajemen Laba Dengan Menggunakan Analisis Jalur. Simposium Nasional Akuntansi VIII, September, 172-194.

Damayanti, C. R., \& Kawedar, W. (2018). Pengaruh Profitabilitas, Mekanisme Pemantauan dan Financial Distress Terhadap Manajemen Laba. Diponegoro Journal of Accounting, 7(4), 1-9.

Dewi, N. L. P. P., \& Noviari, N. (2017). Pengaruh Ukuran Perusahaan, Leverage, Profitabilitas dan Corporate Social Responsibility Terhadap Penghindaran Pajak (Tax Avoidance). E-Jurnal Akuntansi Universitas Udayana, 21(1), 830859. https:// doi.org/10.24843/EJA.2017.v21.i02.p01

Ebtama, A. B., \& Titik, F. (2013). Pengaruh Mekanisme Good Corporate Governance Terhadap Manajemen Laba. Jurnal Akuntansi Dan Keuangan, 15(1), 27-42.

Erawati, T., \& Lestari, N. A. (2019). Pengaruh Perencanaan Pajak (Tax Planning), Kualitas Audit Dan Kepemilikan Institusional Terhadap Manajemen Laba (Studi Empiris Pada Perusahaan Manufaktur Yang Terdaftar di Bursa Efek Indonesia Tahun 2013-2017). Jurnal Akuntansi, 7(1), 98-111. https://doi.org/10.24964/ja.v7i1.686

Gayatrie, C. R. (2014). Skema Bonus Dalam Keputusan Akuntansi Manajer. Jurnal Akuntansi Bisnis Dan Perbankan Indonesia, 22(2), 203-210.

Ghozali, I. (2012). Aplikasi Analisis Multivariate dengan Program IBM SPSS20. Semarang: Badan Penerbit Universitas Diponegoro.

Gunawan, I. K., Darmawan, N. A. S., \& Purnamawati, I. G. A. (2015). Pengaruh Ukuran Perusahaan, Profitabilitas, dan Leverage Terhadap Manajemen Laba. Jurnal Akuntansi Program S1 Universitas Pendidikan Ganesha, 03(1), 1-10.

Jensen, M. C., \& Meckling, W. H. (1976). Theory of the Firm: Managerial Behavior, Agency Costs and Ownership Structure. Journal of Financial Economics, 3(4), 305-360. https://doi.org/http://dx.doi.org/10.1016/0304405X(76)90026-X

Khuwailid, \& Hidayat, N. (2017). Peran Pemoderasi Kepemilikan Institusional pada Pengaruh Beban Pajak Tangguhan, Perencanaan Pajak dan Kepemilikan Manajerial terhadap Manajemen Laba Akrual. Jurnal Riset Akuntansi Dan Perpajakan, 4(1), 117-133.

Koh, P. (2003). On The Association Between Institutional Ownership and Aggressive Corporate Earnings Management in Australia. The British Accounting Review, 35, 105-128. https://doi.org/10.1016/S08908389(03)00014-3

Lidiawati, N., \& Asyik, N. F. (2016). Pengaruh Kualitas Audit, Komite Audit, Kepemilikan Institusional, Ukuran Perusahaan Terhadap Manajemen Laba. Jurnal Ilmu Dan Riset Akuntansi, 5(5), 1-19.

Mahariana, I. D. G. P., \& Ramantha, I. W. (2014). Pengaruh Kepemilikan 
Manajerial dan Kepemilikan Institusional Terhadap Manajemen Laba. EJurnal Akuntansi Universitas Udayana, 7(3), 688-699.

Negara, A. A. G. R. P., \& Suputra, I. D. G. D. S. (2017). Pengaruh Perencanaan Pajak Dan Beban Pajak Tangguhan Terhadap Manajemen Laba. E-Jurnal Akuntansi Universitas Udayana, 20(3), 2045-2072.

Nurrahman, A., \& Sudarno. (2013). Pengaruh Kepemilikan Manajerial, Kepemilikan Institusional, dan Kepemilikan Asing Terhadap Praktik Pengungkapan Sustainability Report. Diponegoro Journal of Accounting, 2(1), $1-14$.

Prasadhita, C., \& Intani, P. C. (2017). Pengaruh Profitabilitas Terhadap Manajemen Laba Perusahaan Consumer Goods Yang Terdaftar Di Bursa Efek Indonesia. Jurnal Riset Akuntansi Terpadu, 10(2), 247-256. https://doi.org/10.35448/jrat.v10i2.4254

Prasetyo, N. C., Riana, \& Masitoh, E. (2019). Pengaruh Perencanaan Pajak, Beban Pajak Tangguhan Dan Kualitas Audit Terhadap Manajemen Laba. Modus, 31(2), 156-171.

Putra, R. H. D. K., Sunarta, K., \& Fadillah, H. (2018). Pengaruh Perencanaan Pajak Dan Beban Pajak Tangguhan Terhadap Manajemen Laba Pada Perusahaan Manufaktur Sub Sektor Makanan Dan Minuman Yang Terdaftar Di Bursa Efek Indonesia Periode 2013-2017. Jurnal Online Mahasiswa (JOM) Bidang Akuntansi, 5(5), 1-16.

Rasid, A. U. (2018). Analisis Profitabilitas Pada PT Fast Food Indonesia Tbk. Gorontalo Management Research, 1(1), 44-59.

Sari, R. N., Hardiyanto, A. T., \& Simamora, P. (2018). Pengaruh Beban Pajak Tangguhan, Perencanaan Pajak dan Profitabilitas Terhadap Manajemen Laba pada Perusahaan Manufaktur yang Terdaftar di Bursa Efek Indonesia Periode 2012-2017. Jurnal Online Mahasiswa Bidang Akuntansi, 5(5), 1-20.

Scott, W. . (2012). Financial Accounting Theory (6th ed). New Jersey: Prentice-Hall International, Inc.

Setyawan, B., \& Harnovinsah. (2016). Pengaruh Beban Pajak Tangguhan, Profitabilitas, dan Perencanaan Pajak Terhadap Manajemen Laba. Keberlanjutan, Jurnal Manajemen Dn Jurnal Akuntansi, 1(1), 15-40.

Sulistyanto, S. (2008). Manajemen Laba Teori dan Model Empiris.

Sumanto, B., Asrori, \& Kiswanto. (2014). Pengaruh Kepemilikan Institusional Dan Ukuran Dewan Komisaris Terhadap Manajemen Laba. Accounting Analysis Journal, 3(1), 44-52. https:// doi.org/10.15294/aaj.v3i1.3901

Sumomba, C., \& Hutomo, Y. S. (2012). Pengaruh Beban Pajak Tangguhan dan Perencanaan Pajak Terhadap Manajemen Laba. Kinerja Journal of Business and Economics, 16(2), 103-115.

Sutrisno, M., Sari, I. A., \& Astuti, Y. P. (2018). Pengaruh Perencanaan Pajak Dan Insentif Non Pajak Terhadap Manajemen Laba Pada Perusahaan Manufaktur yang Terdaftar di Bursa Efek Indonesia Tahun 2013-2017. Permana: Jurnal Perpajakan, Manajemen, Dan Akuntansi, 10(1), 132-148. https://doi.org/10.24905/ permana.v10i2.87

Tala, O., \& Karamoy, H. (2017). Analisis Profitabilitas Dan Leverage Terhadap Manajemen Laba Pada Perusahaan Manufaktur Di Bursa Efek Indonesia. Accountability, 6(1), 57-64. https:/ / doi.org/10.32400/ja.16027.6.1.2017.57-64 
Wibisana, I. D., \& Ratnaningsih, D. (2014). Analisis Faktor - Faktor Yang Mempengaruhi Arah Manajemen Laba (Studi Pada Perusahaan Manufaktur Yang Terdaftar di BEI 2009-2013). E-Jurnal Universitas Atma Jaya, 1-13. http://e-journal.uajy.ac.id

Wild, J. J., Subramanyam, K. R., \& Halsey, R. . (2004). Financial Statement Analysis, (18thed.).

Yahya, A., \& Wahyuningsih, D. (2019). Pengaruh Perencanaan dan Aset Pajak Tangguhan Terhadap Manajemen Laba Pada Perusahaan Manufaktur Yang Terdaftar Di Bursa Efek Indonesia Periode 2013-2017. Sosiohumanitas, XXI(2), 86-92.

Yin, Q. J., \& Cheng, C. S. A. (2004). Earnings Management of Profit Firms and Loss Firms in Response to Tax Rate Reductions. Review of Accounting $\mathcal{E}$ Finance.

Yunila, F., \& Aryati, T. (2018). Pengaruh Perencanaan Pajak dan Pajak Tangguhan Terhadap Manajemen Laba dengan Kualitas Audit Sebagai Variabel Moderasi. Seminar Nasional Cendekiawan, 4, 1021-1027. 